\title{
PRIORITIZATION OF CLIMATE CHANGE ADAPTATION MEASURES USING PARTICIPATORY MULTI-CRITERIA ANALYSIS
}

\author{
Omar H. Al-Sakaf \\ Department of Electrical Engineering, Faculty of Engineering \\ Sana'a University \\ E-mail: alsakafo@maktoob.com
}

(Received April 12, 2007 Accepted, June 11, 2007)

\begin{abstract}
This paper shows how participatory Multi-Criteria Analysis can be successfully used to prioritize potential adaptation measures to climate change. Participatory planning workshops with broad participation of key stakeholders were held to discuss the set of un-prioritized adaptation measures, to solicit input on project priorities based on proposed evaluation criteria. A Multi-Criteria Analysis ranking matrix was used with weighted scores and ranking with great importance attached to some of the criteria as proposed by the participants. In this way, the participants were able - based on 'objective' not 'subjective' selection - to come to shortlists containing the priority climate change adaptation measures for the vulnerable sectors under consideration.
\end{abstract}

KEYWORDS: Adaptation Measures, Climate Change, Prioritization, Multi-Criteria Analysis

\section{INTRODUCTION}

Prioritization is a process whereby an individual or group places a number of items in rank order based on their perceived or measured importance or significance [1]. Due to time and budget constraints, it is often difficult to implement all the requirements that have been elicited for a system. It may also be the case that requirements are to be implemented in stages, and prioritization can help to determine which ones should be implemented first [1].

A multi-stage consultation process to develop Yemen's National Adaptation Program of Action (NAPA), that was based on broad participation of key stakeholders, resulted in one of its stages long lists of potential adaptation measures to climate change for three vulnerable priority sectors; coastal areas \& fisheries, water and agriculture, that were based on sector-specific studies and stakeholders input, see Annex 1 [2]. The primary goal of the NAPA process was to broadly communicate to the international community priority activities that address Yemen's urgent needs for adaptation to the adverse impacts of climate change [2].

Taking the limited resources and timeframe allocated for NAPA preparation into consideration, Stakeholder Groups (SGs) were established in 4 regions according to the land system of Yemen: SG in the Eastern Region (Al-Mukalla), SG in the Coastal Region (Aden and Al-Hodeida), SG in the Middle Region (Dhamar, Ibb and Taiz) and SG in the Northern Region (Sana'a). The SG in the Northern Region represented also a National Stakeholder Group (based in Sana'a) [3]. Different consultative activities and methodologies were implemented at the above mentioned sites at different consultation 
stages of NAPA preparation $[3,4]$. The objectives of the consultative stages were to [5]:

- Groundtruth" the vulnerability synthesis and multidisciplinary assessment reports prepared by sector experts

- Refine key vulnerable geographic areas, sectors, and communities

- Clarify adaptation criteria and priorities

- Identify, prioritize, and select adaptation activities

- Build awareness

The prioritization of the depicted adaptation measures was necessary to have a highest priority shortlist of projects to be implemented in the near future, due to limited committed government and international support.

The main objective of this paper is to highlight the benefits of using the multi-criteria analysis method for prioritizing proposed climate change adaptation measures within a participatory planning context and to demonstrate a very helpful and powerful decision support tool for planners and decision makers.

\section{PARTICIPATORY MULTI-CRITERIA ANALYSIS FOR PRIORITIZATION}

There are several methods available that can be used for prioritizing items or issues, such as [1]:

- Nominal Group Planning Method

- Simplex Method

- Multi-Criteria Analysis (MCA) (Also called: Multi-Criteria Evaluation, Criteria Weighting Method)

- Cost-effectiveness analysis

- Cost benefit analysis

Some methods rely heavily on group participation, whereas other methods are less participatory.

Multi-criteria Analysis (MCA) was chosen for selecting and prioritizing potential adaptation measures since it is particularly applicable to cases where a singlecriterion approach (such as cost-benefit analysis) falls short, especially where significant environmental and social impacts cannot be assigned monetary values. It allows the participants and decision makers to include a full range of social, environmental, technical, economic, and financial criteria, which are required here and best fit this situation [6].

\section{METHODOLOGY}

Figure (1) shows the participatory methodology applied to prioritize the potential adaptation measures. The long lists of potential adaptation measures (see Annex 1) along with the prioritization criteria, which were proposed in earlier consultation stages, served as input.

Two-day workshops were held at five sites, with participants representing all relevant stakeholders, that were already identified based on extensive stakeholders 
analysis [3] (Government authorities, private sector, academic community, research centers, environmental societies, non-governmental organizations NGOs, communitybased organizations CBOs, ... etc). The objectives of the workshops were to discuss the set of un-prioritized adaptation measures, to solicit input on project priorities (based on the criteria proposed) using the MCA ranking matrix.

The participants were subdivided into work groups representing the three vulnerable priority sectors (except in Site 3; Ibb, which is a province with no access to sea, therefore no workgroup for coastal areas \& fisheries). Then they were asked first to check the proposed evaluation criteria to finalize them. Final criteria used for prioritization are depicted in Table (1).

After that, the 'multi-criteria ranking matrix' was explained in detail, as most of the participants have not yet worked with such procedure. It was used with weighted scores and ranking with great importance attached to some of the criteria as proposed by the participants; 'Costs' and 'Poverty Reduction' for example, Table (2).

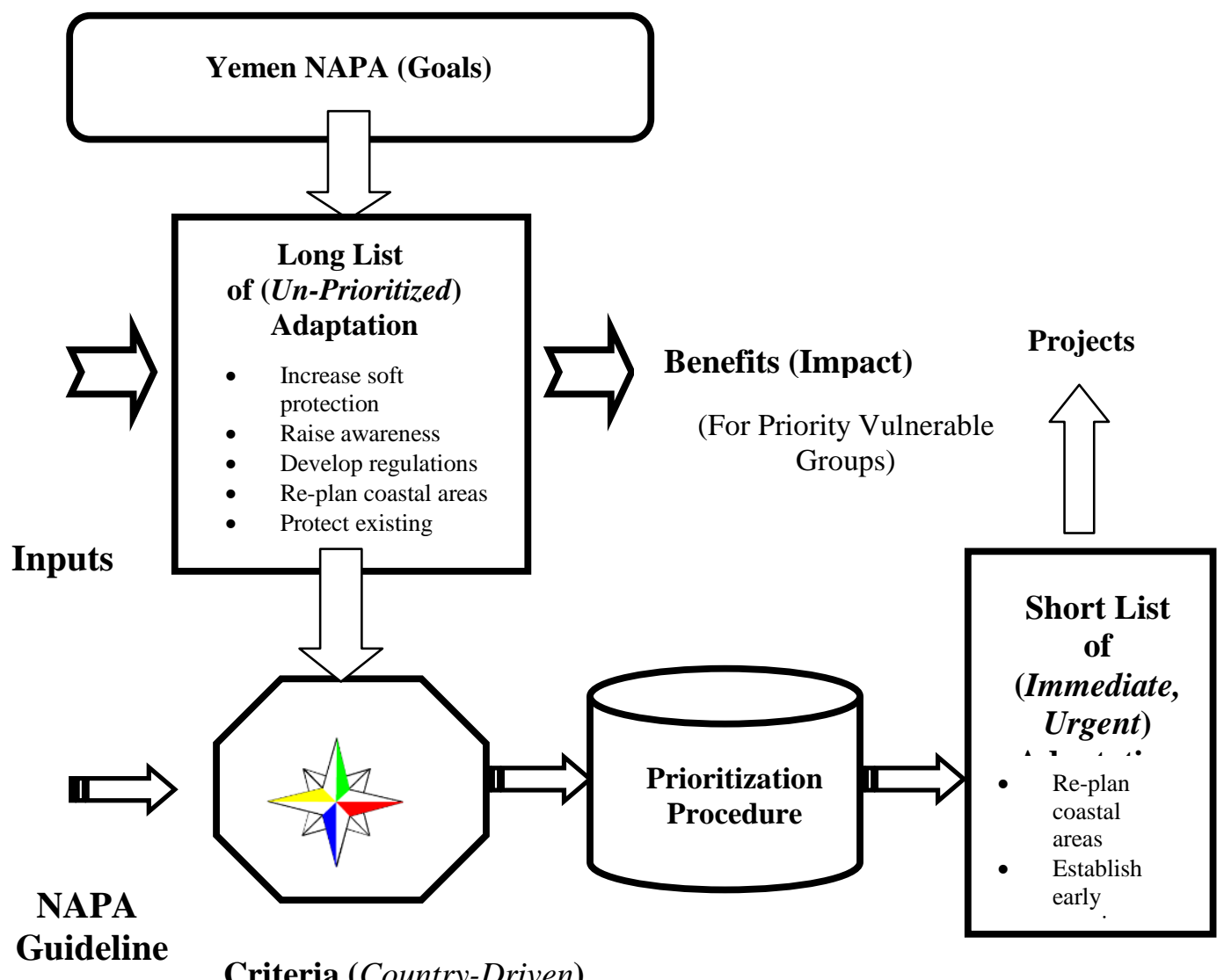

Figure (1): Prioritization Methodology 
Table (1): Final Criteria Used for Prioritization

\begin{tabular}{ll}
\hline Priority Sector & \multicolumn{1}{c}{ Criteria } \\
\hline - Coastal & Contribution to Sustainable Development \\
Areas \& & Security of Livelihoods \\
Fisheries & Poverty Reduction \\
- Water & Synergy with Multilateral Environmental Agreements \\
& Cost \\
\hline Agriculture & Food Security \\
& Security of Livelihoods \\
& Poverty Reduction \\
& Synergy with Multilateral Environmental Agreements \\
& (MEAs) \\
& Cost \\
\hline
\end{tabular}

To calculate the weighted score of an adaptation measure, the relative weight of a criterion was first multiplied by the adaptation measure's standardized score (a number between 0 : 'very negative' and 1: 'very positive', corresponding to 0 to $100 \%$, given by the participants workgroups) for that criterion. Once this is done for each criterion the results are added together, this is the weighted score. For example:

- The weighted score of Measure (1 (Soft protection) is:

$0.111 \times 1.00$ (for the Contribution to Sustainable Development Criterion) + $0.111 \times 0.8$ (for the Security of Livelihoods Criterion) + $0.333 \times 0.6$ (for the Poverty Reduction Criterion) +0.111 x 0.8 (for the Synergy with MEAs Criterion) $+0.333 \times 0.6$ (for the cost criterion) $=0.6882$

- Likewise, that of Measure 4 (Raise awareness of need for coastal adaptation) is:

$0.111 \times 1+0.111 \times 0.8+0.333 \times 0.8+0.111 \times 0.8+0.333 \times 1=0.888$; etc.

This evaluation was implemented very quickly using a spreadsheet (Microsoft Excel), with results being presented via data show directly upon completing scoring by each workgroup.

In this way, the participants were able - based on 'objective' not 'subjective' selection - to come to shortlists containing the priority climate-change adaptation measures for the vulnerable sectors under consideration.

\section{RESULTS}

Table (3) summarizes the results obtained for the five first-priority measures for all three vulnerable sectors at all five sites. The following can be deduced there from:

- The first-priority measure for each site, for each priority sector:

o Measure 5 (Coastal \& Fisheries) for Aden: 'Develop regulations to phase out development in sensitive coastal areas' 
Table (2): The MCA Adaptation Measures Ranking Matrix Used (Sample)

\begin{tabular}{|c|c|c|c|c|c|c|}
\hline \multirow[b]{2}{*}{$\begin{array}{l}\text { ADAPTATION } \\
\text { MEASURES }\end{array}$} & \multicolumn{5}{|c|}{ STANDARDIZED SCORES ON CRITERIA } & \multirow[b]{2}{*}{$\begin{array}{c}\text { MCA } \\
\text { SCORES } \\
(\text { RANKING) }\end{array}$} \\
\hline & $\begin{array}{c}\text { Contribution } \\
\text { to } \\
\text { Sustainable } \\
\text { Development }\end{array}$ & $\begin{array}{l}\text { Security of } \\
\text { Livelihoods }\end{array}$ & $\begin{array}{c}\text { Poverty } \\
\text { Reduction }\end{array}$ & $\begin{array}{c}\text { Synergy } \\
\text { with } \\
\text { MEAs }\end{array}$ & Cost & \\
\hline $\begin{array}{l}\text { Absolute } \\
\text { Weight (1-3) }\end{array}$ & 1 & 1 & 3 & 1 & 3 & Sum $=9$ \\
\hline $\begin{array}{l}\text { Relative } \\
\text { Weight } \\
(1-3) / \text { Sum }\end{array}$ & 0.111 & 0.111 & 0.333 & 0.111 & 0.333 & Sum $=1$ \\
\hline $\begin{array}{l}\text { 1) Increase } \\
\text { soft protection }\end{array}$ & 1 & 0.8 & 0.6 & 0.8 & 0.6 & $\begin{array}{c}0.6882 \\
(25)\end{array}$ \\
\hline $\begin{array}{l}\text { 2) Construct } \\
\text { coastal defense } \\
\text { walls for } \\
\text { coastal areas } \\
\text { subjected to } \\
\text { erosion }\end{array}$ & 0.8 & 0.8 & 0.8 & 0.6 & 0.2 & $\begin{array}{c}0.5772 \\
(31)\end{array}$ \\
\hline $\begin{array}{l}\text { 3) Rely on } \\
\text { technology } \\
\text { (GIS) to } \\
\text { manage } \\
\text { information }\end{array}$ & 0.8 & 0.6 & 0.8 & 0.6 & 0.4 & $\begin{array}{c}0.6216 \\
(28)\end{array}$ \\
\hline $\begin{array}{l}\text { 4) Raise } \\
\text { awareness of } \\
\text { need for } \\
\text { coastal } \\
\text { adaptation }\end{array}$ & 1 & 0.8 & 0.8 & 0.8 & 1 & $\begin{array}{c}0.888 \\
(8)\end{array}$ \\
\hline $\begin{array}{l}\text { 5) Develop } \\
\text { regulations to } \\
\text { phase out } \\
\text { development } \\
\text { in sensitive } \\
\text { coastal areas }\end{array}$ & 1 & 0.8 & 0.8 & 0.8 & 1 & $\begin{array}{c}0.888 \\
(9)\end{array}$ \\
\hline
\end{tabular}

o Measure 22 (Coastal \& Fisheries) for Mukalla: 'Issue licenses for definite types of marine resources and fishes. Specify fishing seasons for each type'

o $\quad$... etc.

- Many same measures are of high priority for more than one site, which reflects shared concerns and common needs, such as:

o Measures for Coastal Areas and Fisheries:

- Number 22: 'Issue licenses for definite types of marine resources and fishes. Specify fishing seasons for each type' in three sites (Mukall, Aden and Taiz) 
- Number 26: 'Capacity building: training/education for use of efficient, marine environment-friendly fishing techniques and equipment' in three sites as well (same sites)

o Measures for Water:

- Number 9: 'Promotion of modern irrigation technologies to increase water use efficiency' in four sites (Aden, Mukall, Ibb and Hodeida)

- Number 21: 'Encourage partnership with users and local communities in the management of water resources, and in financing, operation and maintenance of irrigation and rural water supply projects' in three sites (Aden, Mukall, and Taiz)

o Measures for Agriculture:

- Number 4: 'Apply genetic improvement programs through introduction of drought-, salinity-, heat-, disease- and pest resistant/tolerant varieties/crops, adapting to new crops, collection and documentation of genetic sources and their utilization for plant breeding and improvement programs' in four sites (Aden, Ibb, Taiz and Hodeida),

- Number 22: 'Promote awareness of climatic variability and the potential risk of climate change at all levels of the community (public and decision makers), arrange awareness campaigns to inform farmers on appropriate crops to adapt to emerging salinity and disseminate environmental-agricultural awareness on all levels including school and university curricula' in three sites (Mukalla, Ibb and Hodeida)

- Number 27: 'Activate and enforce existing laws, regulations, ... etc.' in three sites as well (Aden, Mukalla, and Hodeida)

So, a decision on overall priority measures all over Yemen for each sector could be taken based on the above mentioned evaluation; either column 1 measures, or those measures, that are of high priority for more than one site, could be considered as the highest priority shortlist of projects for urgent implementation. In this way, the MCA ranking matrix represents a very helpful decision support tool, that is based on stakeholders participation.

\section{CONCLUSION}

The prioritization of long lists of potential adaptation measures is necessary to rank them and have a highest priority shortlist of projects for urgent implementation. Participatory workshops attended by key stakeholders were held at 5 cities representing the diverse land system of Yemen. Long lists of potential adaptation measures for three vulnerable priority sectors; coastal areas \& fisheries, water and agriculture along with proposed prioritization criteria served as input to the workshops.

Multi-criteria analysis/evaluation is used as participatory prioritization method, which is explained briefly in this paper, and results are presented and analyzed. The MCA ranking matrix represents a very helpful and powerful decision support tool for planners and decision makers. 
Table (3): Results Obtained for the Five First-Priority Measures for All Three Vulnerable Sectors at All Five Sites

\begin{tabular}{|c|l|c|c|c|c|c|}
\hline No. & \multicolumn{5}{|c|}{$\begin{array}{r}\text { First Five Priority Measures } \\
\text { (In order of priority) }\end{array}$} \\
\hline \multicolumn{6}{|c|}{ Coastal Areas \& Fisheries } \\
\hline 1 & Aden & 5 & $\mathbf{7}$ & $\mathbf{2 2}$ & $\mathbf{2 6}$ & 29 \\
\hline 2 & Mukalla & $\mathbf{2 2}$ & $\mathbf{2 6}$ & 10 & $\mathbf{2 1}$ & $\mathbf{7}$ \\
\hline 3 & Ibb & - & - & - & - & - \\
\hline 4 & Taiz & 9 & 15 & $\mathbf{2 6}$ & $\mathbf{2 2}$ & 19 \\
\hline 5 & Hodeida & 30 & $\mathbf{2 1}$ & 20 & 16 & 4 \\
\hline Water Sector & & & & & \\
\hline
\end{tabular}

\begin{tabular}{|c|l|c|c|c|c|c|}
\hline 1 & Aden & $\mathbf{2 1}$ & 28 & 19 & $\mathbf{8}$ & $\mathbf{9}$ \\
\hline 2 & Mukalla & 14 & $\mathbf{9}$ & $\mathbf{1 0}$ & $\mathbf{2 1}$ & 24 \\
\hline 3 & Ibb & $\mathbf{5}$ & $\mathbf{9}$ & $\mathbf{3}$ & $\mathbf{1 8}$ & 2 \\
\hline 4 & Taiz & 13 & $\mathbf{8}$ & $\mathbf{1 8}$ & $\mathbf{2 1}$ & 10 \\
\hline 5 & Hodeida & 1 & 5 & $\mathbf{3}$ & $\mathbf{9}$ & 4 \\
\hline Agriculture &
\end{tabular}

\begin{tabular}{|c|l|c|c|c|c|c|}
\hline 1 & Aden & $\mathbf{8}$ & 3 & $\mathbf{2 7}$ & 6 & $\mathbf{4}$ \\
\hline 2 & Mukalla & $\mathbf{2 2}$ & 24 & $\mathbf{2 7}$ & 5 & 16 \\
\hline 3 & Ibb & $\mathbf{8}$ & $\mathbf{4}$ & 26 & $\mathbf{1 0}$ & $\mathbf{2 2}$ \\
\hline 4 & Taiz & 1 & $\mathbf{4}$ & 9 & 23 & 29 \\
\hline 5 & Hodeida & $\mathbf{2 2}$ & $\mathbf{4}$ & $\mathbf{2 7}$ & 25 & $\mathbf{1 0}$ \\
\hline
\end{tabular}

\section{REFERENCES}

1. Prioritization, www.cdc.gov/od/ocphp/nphpsp/documents/Prioritization.pdf

2. Al-Sakaf, Omar, 'Description of Yemen NAPA Development Consultation Process', Yemen NAPA development project, Environment Protection Authority, October 2006

3. Al-Sakaf, Omar, 'Consultative Assessment Study for Yemen NAPA Development', Yemen NAPA development project, Environment Protection Authority, May, 2005

4. Al-Sakaf, Omar, 'Development of Yemen National Adaptation Program of Action, Compilation Report', Yemen NAPA development project, Environment Protection Authority, June 2006

5. 'Yemen NAPA Final Proposal', Environment Protection Authority, December 2002 
6. 'Compendium on methods and tools to evaluate impacts of vulnerability and adaptation to climate change', UNFCCC Secretariat, January, 2004, http://unfccc.int

\section{ACKNOWLEDGEMENT}

The author as leader of the consultative process for Yemen NAPA development process would like to express his sincere thanks to whole NAPA team and UNDP Office in Yemen for supporting Yemen NAPA development process.

\section{Annex (1)}

\section{Long Lists of Potential Adaptation Measures to Climate Change for all Three Vulnerable Sectors}

\section{Sector 0: COASTAL AREAS \& FISHERIES}

1 Increase soft protection (e.g., beach nourishment and wetland construction and restoration)

2 Construct coastal defense walls for coastal areas subjected to erosion

3 Rely on technology, such as geographic information systems (GIS), to manage information

4 Raise awareness of the need for coastal adaptation that is appropriate for local conditions targeting decision makers and planners down to local community organizations

5 Develop regulations to phase out development in sensitive coastal areas

6 Ensure that new development does not infringe upon the shoreline

7 Re-plan coastal areas in accordance to environmental studies and specifications for protection of marine environment

8 Protect existing investments by maintaining, extending and upgrading existing dyke systems to prevent damage to coastal infrastructure and human activities

9 Construct marine tongues and wave suppressors to avoid waves-induced hazards

10 Establish integrated coastal management network for all coasts of Yemen

11 Establish early warning networks on all sensitive coastal areas and islands along with forecasting functions

12 Establish monitoring/observation centers on Yemeni islands to supervise large liners and ships

13 Control quality of treated waste water discharges (municipal, industrial, ... etc.) via quality control centers established where appropriate

14 Protect coastal eco-tourism and implement market based incentives to promote sustainable tourism 
15 Expand green belt for coastal areas through protection and re-planting of mangroves and palms

16 Conduct studies and research on specific urgent topics

17 Establish 'Yemen Climate Impacts and Adaptation Research Network (YCIARN)' with specialized National Climate Change Research Centers for Priority Vulnerable Sectors

18 Establish 'National Climate Change Research Center for Coastal Areas and Marine Resources' to undertake and coordinate research on immediate and future research needs

19 Set up a national emergency plan to face natural disasters including climate change induced ones

20 Strengthen the capacity and potential of individuals, agencies, and communities in the planning, implementation, monitoring and evaluation of Yemen NAPA projects

21 Activate and enforce marine fishing regulating laws and regulations

22 Issue licenses for definite types of marine resources and fishes

23 Specify fishing seasons for each type

24 Specify fishing areas

25 Reduce current catch on fully and overexploited fisheries to restore health of fisheries

26 Capacity building: training/education on use of efficient, marine environmentfriendly fishing techniques and equipment

27 Raise awareness of fishermen, sailors and all those related to marine environment through guidance and information services

28 Raise awareness of islands inhabitants

29 Involve relevant stakeholders and local communities in monitoring the implementation of valid fishing laws

30 Establish marine protected areas

31 Conduct studies and research on the following:

- Monitoring impact of climate change on marine resources

- Update the eco-graphical information on gulf of Aden and red sea and their impact on fish and marine resources

- Climate change impacts on social and economic condition of population as a result of impact on fisheries resources

- Establish a climate change database

\section{Sector 2: WATER SECTOR}

1 Develop and enforce water quality standards

2 Implement local community-based monitoring systems for water quality 
3 Maximize the use of rainwater through water harvesting techniques in all sectors

4 Develop regulations for water tariffs (prices)

5 Encourage planting of crops with low water requirements (Avoid waterdepleting crops such as Qat, banana, ... etc)

6 Introduce and expand drought-, heat- and salinity-resistant varieties

7 Generalize and enforce environmental impact assessment and water pollution control measures for all projects on all sectors

8 Promote efficient use and equity in water allocation, so as to enhance socioeconomic development and alleviate poverty

9 Promotion of modern irrigation technologies to increase water use efficiency

10 Implement watershed management, terrace rehabilitation and water harvesting project

11 Restore floodplains and coastal ecosystems as buffers against extreme events

12 Develop and implement disaster preparedness and recovery programs, including forecasting, early warning and rapid response

13 Restore or preserve mountain forests to reduce soil erosion and peak-flows

14 Introduce climate change considerations in land use planning and infrastructure design (including planning near to wadies routes, building codes, artificial routes for flowage ... etc.)

15 Encourage and expand water desalination using renewable energy sources, especially on Yemeni islands and coastal areas, where drinking water is not available or subject to seawater intrusion to ensure continuity of life

16 Rely on modern technology, such as geographic information systems (GIS), for water resources management

17 Implement artificial precipitation projects

18 Apply integrated management of water resources, including surface water, groundwater and wastewater

19 Disseminate information on water saving techniques in all economic sectors

20 Adapting minimum environmental flow provisions (surface and groundwater) to the hydro-period of wetlands

21 Encourage partnership with users and local communities in the management of water resources, and in financing, operation and maintenance of irrigation and rural water supply projects

22 Undertake demand-side management measures (end-use technologies, recycling and conservation)

23 Undertake supply-side efficiency improvement measures (leak reduction in delivery systems, optimizing existing water regulation infrastructure (operation and maintenance)

24 Build the capacity of central and local level institutions on the integration of environmental and sustainability issues within the district development process 
25 Promote research on adverse climate change effects on water resources in Yemen and disseminate research results to make use of them

26 Establish 'Yemen Climate Impacts and Adaptation Research Network (YCIARN)' with specialized National Climate Change Research Centers for Priority Vulnerable Sectors

27 Establish 'National Climate Change Research Center for Water Resources' to undertake and coordinate research on immediate and future research needs

28 Promote awareness of climatic variability and the potential risk of climate change at all levels of the community (public and decision makers), arrange local, regional and national awareness raising campaigns to disseminate information on water resources, their vulnerability and adaptation measures on all levels including school and university curricula

\section{Sector 3: AGRICULTURE}

1 Apply efficient integrated natural resources management

2 Apply efficient integrated land management

3 Control and prevent land degradation and desertification

4 Apply genetic improvement programs through introduction of drought-, salinity, heat-, disease- and pest resistant/tolerant varieties/crops, adapting to new crops, collection and documentation of genetic sources and their utilization for plant breeding and improvement programs

5 Improve crop management programs through changing sowing date, crop density, tillage practices, fertilizer levels, growing season for crop, making use of accumulated experience by farmers, collection and documentation of their local knowledge and experience, improving crop specific characteristics (harvest index, photosynthetic efficiency) and mitigation of the effects of drought

6 Apply efficient watershed management

7 Design and implement terrace rehabilitation programs

8 Construct dams where appropriate based on environmental impact assessment and technical and economic feasibility

9 Apply irrigation efficiency improvement programs

10 Apply water use efficiency improvement programs

11 Apply improved irrigation practices such as optimal scheduling high frequency and low-volume water delivery, adequate drainage and salinity control

12 Improve seasonal weather forecast quality

13 Apply traditional technologies, such as multiple cropping and terracing

14 Apply integrated rangeland management

15 Preserve and restore wetlands

16 Compensate water losses by using treated waste water and mosques waters for 
irrigation

17 Promote research on adverse climate change effects on agriculture in Yemen and disseminate research results to make use of them

18 Establish 'Yemen Climate Impacts and Adaptation Research Network (YCIARN)' with specialized National Climate Change Research Centers for Priority Vulnerable Sectors

19 Establish 'National Climate Change Research Center for Agriculture' to undertake and coordinate research on immediate and future research needs

20 Activate the environmental and agricultural extension role in coordination with the different extension departments

21 Conduct studies and research on specific immediate topics

22 Promote awareness of climatic variability and the potential risk of climate change at all levels of the community (public and decision makers), arrange awareness campaigns to inform farmers on appropriate crops to adapt to emerging salinity and disseminate environmental-agricultural awareness on all levels including school and university curricula

23 Establish flexible mechanisms for intervention especially for dealing with Qat and other water-depleting crops through providing for new alternative cropping

24 Undertake measures to avoid adverse effects of urban planning on agricultural land

25 Establish laboratories to test agricultural changes of crops and support existing laboratories at agriculture research centers for adaptation

26 Support alternatives for fuelwood to control woodcutting and preserve plantcover through promotion of LPG use for cooking and solar energy applications for drying, heating, lighting, ... etc.

27 Activate and enforce existing laws, regulations, ... etc.

28 Disseminate flowage/flood guidance stations at main wadies

29 Establish, expand and manage natural protected areas

\section{تحديد أولويات إجراءات التكيف مع التغيرات المناخية بنجاح باستخدام التحليل متعدد

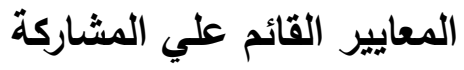

يبين هذا البحث إمكانية استخدام التحليل متعدد المعايير القائم علي المشاركة بنجاح لتحديد الأولويات من الإجراءات الممكنة للتكيف مع التغيرات المناخية ، حيث تم عقد ورشـات عمل تخطيط قائمة علي المشاركة بمشاركة واسعة من الأطراف المعنية الرئيسية لمناقثة مجموعة إجراءات التكيف، التي لم تكن مرتبة بعد، لترنيب المشاريع حسب الأولوية بناء علي معايير التقييم التي سبق اقترحها. 
تم استخدام مصفوفة تحليل وترتيب ذات معايير متعددة لترتيب الإجراءات بحيث يحرز كل إجراء نقاطا

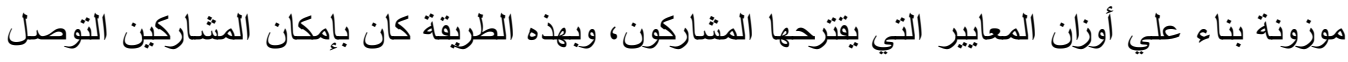
إلي قوائم قصيرة - بناء علي اختيار موضوعي وليس بالتفضيل الثخصي - تحوي إجراءات التكيف ذات الأولوية للقطاعات المأخوذة بالاعنبار والمعرضة للتغيرات المنار مرضوعية. 